\title{
"The Role Of Prosecutors In Preventing Torture And Ill-Treatment Of Accused Persons And Proposals For Reform"1
}

David Baxter Bakibinga²

\section{ABSTRACT}

In the present essay, it is presented an overview of the role of prosecutors in Uganda to prevent torture and ill treatment of accused persons, specifying the duties of the prosecutors in this matter, giving as well some information about the mandate of the Office of the Director of Public Prosecutions and also the types of Prosecutors existing in Uganda in the present time. Lastly, suggests the need of reforms aiming better investigations about torture crimes perpetrated in that country.

Keywords: Public Prosecution. Uganda. Torture Prevention. Duties and challenges.

1 Data de recebimento: 03/04/2018. Data de aceite: 18/06/2018.

2 David Baxter Bakibinga is a Lawyer by training and a holder of a Bachelor of Laws (LLB) (Honours) (MUK), LLM (MUK), LLM in International Criminal Law, National University of Ireland, Galway. He holds a Diploma in Legal Practice, LDC and a Diploma in Public Administration and Management, UMI. He is an Advocate of the High Court of Uganda. He has worked as a public prosecutor with the Office of the Director of Public Prosecutions (ODPP), Uganda for over 18 years. He is currently the Deputy Regional Officer, Nakawa ODPP Regional Office. He is also the President of the Uganda Association of Prosecutors (UAP) an umbrella body that advocates for collective rights of public prosecutors under the ODPP. David manages a number of corporate entities that deal in real property, investment, development, education and public health. David's areas of interest include International Criminal Law and Justice; Counter-Terrorism and Human rights: Arms Management and Regulation; Combating Organised Crime; Law and Governance; Policy Analysis; Sustainable Human Development, International Humanitarian Law and Peace Operations and Transitional Justice. 


\section{INTRODUCTION}

The Office of the Director of Public Prosecutions (ODPP) is a crucial agency of government in ensuring the proper functioning and administration of the criminal justice system in Uganda. ${ }^{3}$ Uganda is a common law jurisdiction. Under criminal proceedings, the law places the burden of proof on the prosecution to establish the guilt of an offender. ${ }^{4}$ Criminal proceedings in Uganda are instituted in the name of the state. ${ }^{5}$ The DPP is mandated by the 1995 Constitution of the Republic of Uganda to direct and control criminal proceedings on behalf of the public. ${ }^{6}$ The Prevention and Prohibition of Torture Act among many laws enjoin the DPP to prosecute offenders who engage in the practice of torture. The legislation against torture lays emphasis on preventing abuse of authority and or power.

This paper examines the role of DPP in preventing and prohibiting torture against the accused persons.

\section{AN OVERVIEW OF THE PROSECUTION SERVICE IN UGANDA}

The DPP is the office or official charged with the prosecution of criminal offences in several criminal jurisdictions around the world. The title is used mainly in jurisdictions that are or have been members of the Commonwealth of Nations.

In prosecuting matters, the Director acts on behalf of the community. Prosecutors have strikingly been called "ministers of justice", a phrase which sums up the unique position of the prosecutor in the criminal justice system. ${ }^{7}$ It has been said that pro-

\footnotetext{
3 Wagona, V. (2014). Present Situation, Problems and Solutions in the Legal System Related to Corruption Control in Uganda. 8th International Training Course on Corruption Control in Criminal Justice, Resource Material Series, (71).

4 Woolmington v DPP [1935] AC 462 at 481-482.

5 Article 250 (4) of the 1995 Constitution of the Republic of Uganda, Vol. 1 Chapter 1, Laws of Uganda. 6 Article 120 of the 1995 Constitution of the Republic of Uganda, Vol. 1 Chapter 1, Laws of Uganda. 7 Medwed. Daniel S. (2009). The Prosecutor as Minister of Justice: Preaching to the Unconverted from the Post-Conviction Pulpit. Wash. L. Rev., 84, 35.
} 
secutors must always act with fairness and detachment with the objectives of establishing the whole truth and ensuring a fair trial. ${ }^{8}$ Although the DPP does not have clients as such, in performing its functions the Office works closely with the Courts, the legal profession, police and other investigators, victim's representatives and other government agencies. This ensures that appropriate consideration is given to the concerns of victims of crime.

In the exercise of their work Prosecutors engage in decision making that is in the context of the law and profoundly subjective. ${ }^{9}$ This is so because the law requires discretionary authority to make it work. In exercising this discretion, the Prosecutor must take public policy into consideration.

\section{THE OFFICE OF THE DIRECTOR OF PUBLIC PROSECUTIONS: THE MANDATE}

The DPP's mandate ${ }^{10}$ includes: to direct the police to investigate any information of a criminal nature and to report to him or her expeditiously; to institute criminal proceedings against any person or authority in any court with competent jurisdiction other than a court martial; to take over and continue any criminal proceedings instituted by any other person or authority; ${ }^{11}$ to discontinue at any stage before judgment is delivered, any criminal proceedings to which this article relates, instituted by himself or herself or any other person or authority; except that the DPP shall not discontinue any proceedings commenced by another person or authority except with the consent of the court.

8 Green, B. A. (1998). Why should prosecutors seek justice. Fordham Urb. LJ, 26, 607. 9 Shermer, L. O. N., \& Johnson, B. D. (2010). Criminal prosecutions: Examining prosecutorial discretion and charge reductions in US federal district courts. Justice Quarterly, 27 (3), 394-430.

10 See Article 120 (3) of the 1995 Constitution of the Republic of Uganda, Laws of Uganda Chapter 1, Volume 1

11 Nsereko, D. D. N. (2005). Prosecutorial Discretion before National Courts and International Tribunals1. Journal of International Criminal Justice, 3(1), 124-144. 
The DPP in the exercise of his or her functional powers is independent and is not subject to directions or control of any person or authority. This ensures that the DPP executes his or her mandates without fear or favour. ${ }^{12}$

\subsection{A Prosecutor}

This is a government appointed attorney or lawyer or officer who initiates and pursues court cases against suspected criminals or persons who are suspected of breaking the law. ${ }^{13}$ The prosecutor guides police to collect the right evidence. This evidence is compiled into a police file and includes statements, reports, and documents among others. The prosecutor then presents the evidence before court and makes legal arguments.

\subsection{Types of Prosecutors}

\section{Public prosecutors:}

Public prosecutors in Uganda are in two categories namely those appointed by the Public Service as State Attorneys and State Prosecutors. The other category are those provided for under statute but appointed and regulated by the DPP. ${ }^{14}$ State Attorneys and State Prosecutors under DPP enjoy a right of audience before the courts under the general practicing license of DPP under the Advocates Act. Under S. 224 Magistrates Courts Act (MCA), public prosecutors are empowered to appear and proceed before any magistrate court without any express written authority. It should be noted that State Prosecutors have no right of audience before the High Court, Court of Appeal and Supreme Court due to the fact that they are not advocates. ${ }^{15}$

12 See Article 120 (6) of the Constitution.

13 Zhen, F. A. N. G. (2011). Role Definition of Prosecutor in the Criminal Trial: From the Perspective of Prosecution and Defense Equality [J]. Journal of Central South University of Forestry \& Technology (Social Sciences), 1, 011.

14 See S.223 of the Magistrates Courts Act, 1970 Vol. 2 Chapter 16 Laws of Uganda.

15 See S. 136 of the Trial on Indictments Act, 1970 Vol. 2 Chapter 23 Laws of Uganda. 


\section{Private prosecutors:}

Private prosecutions are only conducted in Magistrates courts. They are provided for under Sections 42 (3) and 43 of the MCA. They are under the direction and control of the court. This is to ensure that there is no abuse of the legal process and that frivolous and vexatious cases are not instituted. A private prosecutor may be a complainant or a private advocate instructed to lodge a complaint on oath. However, these are limited to non-indictable offences such as torture.

\subsection{The role and duties of the prosecutor}

Prosecutors play a crucial role in the criminal justice process. They are the lynch pin between the investigating bodies and the judiciary. ${ }^{16}$ In doing so they have to be guided by the law and evidence. The prosecutor is enjoined to assist the court in arriving at the truth of the matter in dispute and in securing justice. As was explained in $R v$ Lucas [1973] VR 693 at 705 in 1972 by Newton J and Norris AJ:

It is very well established that prosecuting counsel are ministers of justice, who ought not to struggle for a conviction nor be betrayed by feelings of professional rivalry, and that it is their duty to assist the court in the attainment of the purposes of criminal prosecutions, namely to make certain that justice is done as between the subject and the State...We may add that these obligations which attach to prosecuting counsel apply, in our opinion, to officers in the service of the Crown whose function is to prepare the crown case in criminal proceedings.

A prosecutor's duty of neutrality is encapsulated in a Latin maxim "pro domina Regina as pro domina Veritae.", meaning the prosecutor

16 Davis, A. J. (2007). Racial fairness in the criminal justice system: The role of the prosecutor. Colum. Hum. Rts. L. Rev., 39, 202. 
is not a minister of the monarch or state but is rather to be viewed as a minister of truth. ${ }^{17}$ It follows that a prosecutor must facilitate the justice process to ensure that the truth is the end result.

\section{The duty to ensure that witnesses are protected:}

It has been emphasized that it's the prosecutor's duty to ensure that the witnesses who offer to give testimony are protected prior, during and after court. ${ }^{18}$ This is done through cooperating with police or the witness protection agencies. The prosecutor is enjoined in conducting a threat assessment to determine the nature of protection to be rendered to a given witness. ${ }^{19}$ The protection can range from in court measures including use of pseudonyms, facial disguise, voice distortion, police protection to relocation to other countries. ${ }^{20}$ The practice in Uganda however is that only witnesses in Domestic violence, Torture, Terrorism and war crime cases are usually afforded protection. There is a Witness Protection Bill in the offing which will provide for the framework protective measures for vulnerable witnesses and victims. ${ }^{21}$ It should be emphasized that as prosecutors execute the duty to protect, witnesses are also obliged to afford maximum cooperation. Otherwise there would be failure and the consequences of failure can be dire..$^{22}$

\footnotetext{
17 Waite, P. B. (1984). An Attorney General of Nova Scotia, JSD Thompson, 1878-1882: Disparate Aspects of Law and Society in Provincial Canada. Dalhousie LJ, 8, 165.

18 Goldstein, A. S. (1984). The victim and prosecutorial discretion: The federal victim and witness protection act of 1982. Law and contemporary problems, 47(4), 225-248.

19 Yaroshefsky, E. (2009). Enhancing the Justice Mission in the Exercise of Prosecutorial Discretion. Temp. Pol. \& Civ. Rts. L. Rev., 19, 343.

20 Eikel, M. (2012, September). Witness Protection Measures at the International Criminal Court: Legal Framework and Emerging Practice. In Criminal Law Forum (Vol. 23, No. 1-3, pp. 97-133). Springer Netherlands.

21 Moffett, L. (2016). Complementarity's Monopoly on Justice in Uganda: The International Criminal Court, Victims and Thomas Kwoyelo. International Criminal Law Review, 16(3), 503-524.

22 Anyeko, K., Baines, E., Komakech, E., Ojok, B., Ogora, L. O., \& Victor, L. (2012). 'The Cooling of Hearts': Community Truth-Telling in Northern Uganda. Human Rights Review, 13(1), 107-124.
} 


\section{The duty to support victims of crime and ensure they get justice:}

The prosecutor has an obligation to ensure that victims of crime are given the necessary support. ${ }^{23}$ The office of DPP Uganda established the Department of Victim Support and Witness Protection. ${ }^{24}$ The victims are referred for psychosocial support and other interventions including medical care. The referrals are made to hospitals or Civil Society Organizations. The ODPP also handles complaints filed by victims of crime and ensure that the interests of justice are served.

\section{The duty to disclose both inculpatory and exculpatory evidence:}

Disclosure simply put is the uncovering of evidence and other information between parties of legal proceedings before and during the proceedings. ${ }^{25}$ The right to disclosure is premised on the minimum standards established by major human rights instruments. It follows that an accused person has a right to information as concerns the charges and must be accorded adequate time and facilities for the preparation of the defence. ${ }^{26}$ The prosecutor is required to disclose incriminating evidence but this is subject to the protection and privacy of the victims and witnesses. ${ }^{27}$ Where the safety or privacy of witnesses or victims or if disclosure would be prejudicial to an ongoing investigation ${ }^{28}$, the prosecutor may disclose summarised evidence or redacted versions of the same. ${ }^{29}$

23 Mbazira, C., \& Mubangizi, J. C. (2014). The victim-centred approach in criminal prosecutions and the need for compensation: reflections on international approaches and the legislative and policy frameworks in Uganda and South Africa. Comparative and International Law Journal of Southern Africa, 47(2), 206-224.

24 http://www.dpp.go.ug/index.php/component/k2/item/17-victim-s-rights-and-victim-centeredapproach accessed on 30/03/2018.

25 Safferling C., International Criminal Procedure, Oxford, 2012, p346.

26 See Articles 14(3)(a) and (b) ICCPR and Article 6(3)(a) and (b) ECHR.

27 Article 68(5) ICC Statute.

28 Rule 81 (2) RPE.

29 ICC Prosecutor v Lubanga, AC, ICC-01/04-01/06-774 (OA6), 14 December 2006, Judgement on the Appeal of Mr Thomas Lubanga Dyilo against the Decision of the PTCI entitled ' Second Decision on the 
The US Supreme Court in Brady v Maryland ${ }^{30}$ ruled that: "The suppression by the prosecution of evidence favourable to an accused upon request violates due process where the evidence is material either to the guilt or to punishment, irrespective of the good faith, or bad faith of the prosecution". ${ }^{31}$

Disclosure of redacted and or summarized evidence is a safety net to protect victims, witnesses and survivors of torture. ${ }^{32}$ Victims and witnesses to serious crimes are always vulnerable and face a high risk of reprisals. ${ }^{33}$ It follows that prosecutors must act candidly and prudently in ensuring their safety.

\section{The duty to prevent injustice, abuse of process and protect the innocent:}

The prosecutor's obligation to prevent injustice, abuse of the legal process and protection of the innocent is provided for by law. ${ }^{34}$ This obligation is executed through prosecutorial discretion judiciously. ${ }^{35}$ Offenders or those suspected of committing crime should on be charged premised on the evidence and in accordance with the law. In order to protect the innocent from the excess of the law enforcement agencies, the DPP is granted constitutional powers to enter Nolle Prosequi and to consent to charges. ${ }^{36}$ The power of the DPP is unfettered, that is, not subject to control and directions of any person or authority. ${ }^{37}$ The failure by DPP and or the prosecutors would result in cruel and degrading treatment of the innocent.

Prosecution Requests and amended requests for Redactions under Rule 81', para 35.

30373 U.S 83 (1963).

31 Ibid p. 87.

32 Mahony, C. (2010). The justice sector afterthought: Witness protection in Africa.

33 https://www.unodc.org/cld/en/legislation/bih/law_on_protection_of_witnesses_under_threat_ and_vulnerable_witnesses/chapter_i-iv/article_1-27/law_on_protection_of_witnesses_under_threat_ and_vulnerable_witnesses.html accessed on 29/03/2018 .

34 Article 120 (5) of the 1995 Constitution of the Republic of Uganda. "(5) In exercising his or her powers under this article, the Director of Public Prosecutions shall have regard to the public interest, the interest of the administration of justice and the need to prevent abuse of legal process."

35 Dong, J. (2009). Prosecutorial Discretion at the International Criminal Court: A Comparative Study. J. Pol. \& L., 2, 109.

36 Article 120 (3) ibid, Section of the Trial on Indictments Act and Section of the Magistrates Courts Act. 37 Article 120 


\section{Torture}

Torture was not a crime in Uganda until 2012. Most of the perpetrators of this crime were actors from the public sector especially law enforcement and security. ${ }^{38}$ The unique innovation under the Prevention and Prohibition of Torture Act is that it covers also private perpetrators. The perpetrator need not be a person in authority as it were. The Act does criminalize torture and proscribes penalties. ${ }^{39}$ Previously Uganda used to rely on the common criminal offences such as assault, causing grievous harm and unlawful wounding to punish acts of torture. This was deemed by the international human rights community as a lack of action against the vice of torture until 2012 when the Act was enacted.

Under the Act, torture means any act or omission, by which severe pain or suffering whether physical or mental is intentionally inflicted on a person by or at the instigation of or with the consent or acquiescence of any person whether a public official or other person acting in an official or private capacity for such purposes as -

(a) obtaining information or a confession from the person or any other person;

(b) punishing that person for an act he or she or any other person has committed, or is suspected of having committed or of planning to commit; or

(c) intimidating or coercing the person or any other person to do, or to refrain from doing, any act. ${ }^{40}$ The definition encompasses torture perpetrated by both public and private actors. There had been a school of thought that focused on only the public actors.

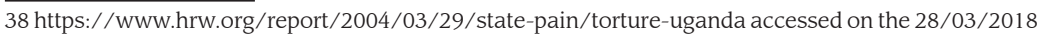
39 See Sections 4- criminalization of torture which proscribes a penalty of 15 years imprisonment or a fine of $7,200,000 /=$ Ugx.

40 Section 2. Definition of torture of The Prevention and Prohibition of Torture Act, 2012 


\section{The legal framework to combat torture}

The Torture Act provides for the offence of Aggravated Torture. ${ }^{41}$ The aggravating circumstances include where the victim of torture dies; where the victim is infected with HIV/AIDS; offender uses or threatens to use or used a deadly weapon; offender uses or used sex as a means of torture; victim was a person with a disability; victim was pregnant or becomes pregnant; the victim was subjected to medical experiments; victim was under the age of 18 years; the victim is incapacitated; the act of torture is recurring; offender commits any act which court considers aggravating.

The Act also criminalizes cruel, inhuman or degrading treatment or punishment. ${ }^{42}$ The most reported violations were in police custody and remand prisoners. ${ }^{43}$ This was a positive step to prevent this form of abuse.

The procuration, aiding and abetting, inciting, financing of torture among others is criminalized. ${ }^{44}$ This is meant to deter especially the private actors in using torture to pursue their agenda.

Accessories after the fact of torture are also punishable under the law. ${ }^{45}$ The accessories are those who enable one escape punishment or enable the offender elude law enforcement actors.

The provision on superior responsibility for offences of subordinates is meant for commanders in the armed forces or the security agencies. ${ }^{46}$ The superiors are responsible to ensure discipline among their rank and file. Where there are torture allegations and no action is taken then they are liable for the offences by their subordinates.

41 Section 5 of the PPTA and the maximum sentence for the offender is life imprisonment. 42 Section 7 of the PPTA and the maximum penalty is 7 years imprisonment and or a fine of Three Million three hundred and sixty thousand Uganda shillings.

43 http://www.monitor.co.ug/News/National/Torture-cases-on-the-rise/688334-3215752-q7h9jjz/ index.html

44 Section 8 of the Act and the maximum penalty is 7 years imprisonment and or a fine of Three Million three hundred and sixty thousand Uganda shillings.

45 Section 9 of the Act and the maximum penalty is 7 years imprisonment and or a fine of Three Million three hundred and sixty thousand Uganda shillings.

46 Section 10 of the Act. 
The Act prohibits the use of information obtained by torture. ${ }^{47}$ This is meant to cover investigators, prosecutors and judicial officers. They are required to reject evidence obtained through torture.

\section{Other laws prohibiting torture in Uganda}

The Anti-Terrorism Act 2002 was the first legislation to specifically criminalize torture, inhuman and degrading treatment, and illegal detention or intentionally causes harm or loss to property. ${ }^{48}$ This was meant to prevent the counter terrorism investigators from using torture as a technique.

The Penal Code Act also prohibits unlawful wounding and similar acts by persons in authority. ${ }^{49}$ These are offences endangering life or health of a person. Some officers for instance the police are mandated to use reasonable force in effecting arrests. Where excessive or unnecessary force is used then they would be liable for unlawful wounding.

In Gäfgen v Germany, ${ }^{50}$, the deputy chief of the Frankfurt police and the detective officer who had threatened Gäfgen with torture were prosecuted and convicted for coercion and sentenced to a suspended fine.

Further illustration by the courts in opposing the practice of torture was made by the House of Lords, in Al Skeini and Others $v$ Secretary of state for defence and Others, ${ }^{51}$ where the killing of Baha Mousa led to the House of Lords ruling that the provisions of the ECHR extended to UK detention facilities abroad and as a result a comprehensive public inquiry was held. The inquiry found that there were corpo-

\footnotetext{
47 Section 15 of the Act and the maximum penalty is 2 years imprisonment and or a fine of Nine hundred and Sixty thousand shillings only

48 See Section 21 (e) of the Anti-Terrorism Act: Any authorised officer who engages in torture, inhuman and degrading treatment, illegal detention or intentionally causes harm or loss to property commits an offence.

49 Section 222 of the Penal Code Act and the maximum penalty is 5 years imprisonment.

50 Application no. 22978/05.

51 [2007] UKHL 26.
} 
rate failures within the Ministry of Defence over the use of banned interrogation techniques. ${ }^{52}$ A subsequent ECtHR decision found that the UK's Convention obligations extend to alleged unlawful killings even if they take place outside of detention facilities. ${ }^{53}$

\section{The specific role of the DPP in protection of accused persons}

In the forth place, the DPP must uphold the constitutional rights such as the 48 hour rule of those suspected of committing crime. ${ }^{54}$ This is through exercising control over investigations by guiding police to ensure that there is respect and promotion of rights of suspects. Proactive policing and investigations should be advocated for in place of reactive investigations. This would ensure that arrests are made when there is reasonable and probable cause to enable the suspect to appear before court within the 48 hours.

Also, the DPP exercises control over private prosecutions even in cases related to torture. ${ }^{55}$ Private prosecutors can prosecute individuals who commit torture crimes. However, the law enjoins DPP to take over where the particular case requires adequate resources for appropriate investigations. This is to ensure that the interests of justice are safeguarded and prevent abuse of the process.

Also, the DPP is enjoined to reject illegally obtained evidence through torture. ${ }^{56}$ Evidence obtained through torture cannot be a basis of prosecution. The rationale is that by permitting evidence obtained through torture, compromises the credibility and fairness of the criminal justice process. Prosecutors are the gatekeepers for

52 Baha Mousa Public Inquiry available at: http://www.bahamousainquiry.org/report/index.htm 53 Al Skeini and Others v United Kingdom (Application no. 55721/07), available at: http://www.unhcr. org/refworld/docid/4e2545502.html

54 Gershman, B. L. (2005). Prosecutorial Ethics and Victim's Rights: The Prosecutor's Duty of Neutrality. Lewis \& Clark L. Rev., 9, 559.

55 See Section. 13 of the Prevention and Prohibition of Torture Act (PPTA).

56 Section 14 PPTA. 
the rights of suspects and accused persons ${ }^{57}$, when such evidence is rendered illegal, this acts as a deterrence to the practice of torture by law enforcement actors.

Fourthly prosecutor must handle complaints from alleged tortured suspects and accused persons. This is a constitutional obligation bestowed upon the office of the DPP to prevent the abuse the legal process and protect the public interest. ${ }^{58}$ The ODPP has established a Complaints Desk to ensure the fulfilment of the mandate.

Fifthly the DPP is obligated to prosecute torture suspects. This must be done based on the evidence and in accordance with the law. The prosecution of law enforcement actors whereas it is a challenge but has to be done without fear or favor. Any compromise would render the criminal justice process impotent and partial.

As well, the DPP is empowered to terminate cases where accused persons were tortured by entering Nolles or Withdrawal Forms. ${ }^{59}$ The powers to terminate cases by the DPP are unfettered but must be exercised in the public interest. This gives the DPP the flexibility in managing such cases.

Lastly, the DPP must consent to charges under the Torture Act against non-citizens. ${ }^{60}$ The requirement for consent is ensure that it is the DPP to authorize the prosecution in respect of torture allegations. This may serve the purpose of preventing false allegation against non-citizens with serious diplomatic ramifications in their countries. The other reason is to ease the pressure on the police and prosecutors ensuring justice for the victims.

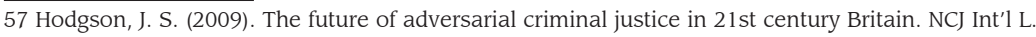
\& Com. Reg., 35, 319.

58 Article 120 (5) of the 1995 Constitution of the Republic of Uganda.

59 Article 120 (3) of the Constitution. See also Section 134 of the Trial on Indictments Act and S. 121 of the Magistrates Court Act

60 Section 19 of the PPTA 


\section{Challenges faced by DPP in executing its mandate}

The biggest challenge is the reported use of torture during criminal investigations and in counter-terrorism. This follows the practice of enhanced interrogation techniques by the US and UK post 9/11. The practices of torture seemed to have been rationalized. Uganda has since converted the Nalufenya police station into a Guantanamo Bay of sorts. ${ }^{61}$ The mere mention by an accused person that he was interviewed from Nalufenya immediately raises a red flag. The mayor for Kamwenge Town Council who had been arrested on allegations of treason was literary butchered as chunks of his flesh were cut off his knees and ankles. ${ }^{62}$

The other challenge is that the DPP has no control over Police Professional Standards Unit (PSU). When citizens report cases including those of torture to the PSU, many are never investigated and errant officers punished. ${ }^{63}$ Even cases referred to PSU are often given the due attention. Officers are often only transferred from one location to another or sent for further training to allow passage of time.

The Uganda police is militarized. ${ }^{64}$ Military personnel are simply given police uniform and deployed without undergoing police training. For the last 16 years, military officers have and continue to operate at the helm of the police leadership. This has fomented an environment of human rights abuse against suspects and those from the political opposition. The presence of military officers presents a unique or even queer situation for DPP to have the effective control of prosecutions and investigations when their mandate orientation is different.

The prosecution of torture victims before the court martial ${ }^{65}$ pla-

\footnotetext{
$61 \mathrm{http}: / /$ allafrica.com/stories/201705220034.html accessed on the 25/03/2018.

62 https://www.independent.co.ug/nalufenya-innocents-tortured-confess/2/ accessed on the 25/03/2018.

63 https://ugfacts.com/uganda-police-professional-standards-unit/ accessed on 20/03/2018. 64 Kagoro, J., \& Biecker, S. (2014). For whom do the police work? The Ugandan police between militarization and everyday duties. Institute for Intercultural and International Studies, University of Bremen. 65 https://www.hrw.org/report/2011/07/27/righting-military-injustice/addressing-ugandas-unlawfulprosecutions-civilians accessed on 21/03/2018.
} 
ces their plight out of reach of the DPP. The DPP has a constitutional limitation of not pursuing matters before the court martial or military courts. The practice is that where a person has been tortured but there is no basis to prosecute them, then allegations that they have in their possession items meant for the military are preferred. This would technically qualify them to be subject of military law. DPP is estopped from pursuing such matters.

The lack of an enabling ODPP Law impacts on its operations. ${ }^{66}$ The office executes its mandate under one constitutional provision and scattered provisions in a number of legislations. The absence of a legislation impacts on how the institution is facilitated in order to execute its mandate. It follows that there is partial functionality in pursuing abuse of the legal processes and protecting the public interest.

There is limited reporting of torture cases to ODPP. Many torture victims for fear of reprisals do not report cases. The DPP Complaints Desk is not well equipped to pursue most of the cases as there is reliance on the same institutions accused of the abuse to investigate and furnish reports.

The DPP lacks a monitoring unit for detention facilities such as Nalufenya. This denies it the privilege of having firsthand information as regards the situation that prevails in the detention facilities.

\section{Proposed Reforms}

There is need for an independent Police Professional Standards body comprised Uganda Police, ODPP - Office of the Director of Public Prosecutions, Inspector General of Government, Judiciary, Uganda Human Rights Commission to deal with torture investigations.

There is need to amend the Evidence Act to remove confessions from the mandate of police officers. ${ }^{67}$ The mandate should

66 https://ugandaradionetwork.com/story/dpp-wants-autonomy-chibita accessed on 01/04/2018. 67 The Charge and Caution Statements: Sections 23 and 25 Evidence Act, Chapter 6 volume II, Laws of Uganda 2000 and The Chief Justice's Rules 1970. 
be given to a quasi-judicial authority under the Justice ministry who should be well trained in criminal investigations akin to Juge $d^{\prime}$ instruction or investigating magistrate ${ }^{68}$ under Napoleonic Code or Civil Law countries.

The need for enactment of an enabling law for the ODPP to enable its proper fulfilment of its mandate.

There is need for staff reorientation on separation of powers in the Rule of Law sectors, re-skilling middle to senior staff in Police on civilian-police relations and the removal of a military officers from the police. ${ }^{69}$

The ODPP must have an outreach program to deal with prevention of torture. The public must be empowered through engagement with the communities, education and media campaigns. ${ }^{70}$ This would enable the public to report torture.

Lastly, there is the need for an ODPP monitoring unit of detention centres to ensure that there is compliance with the law during interviews, duration of detention and treatment of suspects since it has an impact on the credibility and functionality of the criminal justice system. ${ }^{71}$

\section{RESUMO}

Neste trabalho, é apresentado um panorama do papel dos promotores de justiça em Uganda para a prevenção da tortura e maus tratamentos de pessoas acusadas de crimes, especificando as obrigações dos promotores nesta questão, bem como trazendo informações sobre o

\footnotetext{
68 Hodgson, J. (2001). The police, the prosecutor and the juge d'instruction: Judicial Supervision in France, theory and practice. British Journal of Criminology, 41 (2), 342-361.

69 Baker, B. (2007). Conflict and African police culture: the cases of Uganda, Rwanda and Sierra Leone. In Police Occupational Culture (pp. 321-347). Emerald Group Publishing Limited.

70 Kira, I. A. (2002). Torture assessment and treatment: The wraparound approach. Traumatology, 8(2), 54.

71 Payne-James, J., Beynon, J., \& Vieira, D. (Eds.). (2017). Monitoring Detention, Custody, Torture and Ill-treatment: A Practical Approach to Prevention and Documentation. CRC Press.
} 
mandato do Gabinete do Diretor dos Promotores de Justiça e também os tipos de Promotores existentes em Uganda atualmente. Por fim, sugere a necessidade de reformas visando a melhoria das investigações sobre crimes de tortura no país.

Palavras-chave: Ministério Público. Uganda. Prevenção da tortura. Atribuições e desafios.

\section{REFERENCES}

\section{Books}

Safferling C., International Criminal Procedure. Oxford, 2012

\section{Articles}

ANYEKO, K., Baines, E., Komakech, E., Ojok, B., Ogora, L. O., \& Victor, L. (2012). 'The Cooling of Hearts': Community Truth-Telling in Northern Uganda. Human Rights Review, 13(1), 107-124.

BAKER, B. (2007). Conflict and African police culture: the cases of Uganda, Rwanda and Sierra Leone. In Police Occupational Culture (pp. 321-347). Emerald Group Publishing Limited.

DAVIS, A. J. (2007). Racial fairness in the criminal justice system: The role of the prosecutor. Colum. Hum. Rts. L. Rev., 39, 202.

DONG, J. (2009). Prosecutorial Discretion at the International Criminal Court: A Comparative Study. J. Pol. \& L., 2, 109.

EIKEL, M. (2012, September). Witness Protection Measures at the International Criminal Court: Legal Framework and Emerging Practice. In Criminal Law Forum (Vol. 23, No. 1-3, pp. 97-133). Springer Netherlands.

GERSHMAN, B. L. (2005). Prosecutorial Ethics and Victim's Rights: The Prosecutor's Duty of Neutrality. Lewis \& Clark L. Rev., 9, 559.

GOLDSTEIN, A. S. (1984). The victim and prosecutorial discretion: The federal victim and witness protection act of 1982. Law and contemporary problems, 47(4), 225-248. 
GREEN, B. A. (1998). Why should prosecutors seek justice. Fordham Urb. LJ, $26,607$.

HODGSON, J. S. (2009). The future of adversarial criminal justice in 21 st century Britain. NCJ Int'l L. \& Com. Reg., 35, 319.

HODGSON, J. (2001). The police, the prosecutor and the juge d'instruction: Judicial Supervision in France, theory and practice. British Journal of Criminology, $41(2), 342-361$.

KAGORO, J., \& Biecker, S. (2014). For whom do the police work? The Ugandan police between militarization and everyday duties. Institute for Intercultural and International Studies, University of Bremen.

KIRA, I. A. (2002). Torture assessment and treatment: The wraparound approach. Traumatology, 8(2), 54.

MAHONY, C. (2010). The justice sector afterthought: Witness protection in Africa.

MBAZIRA, C.; MUBANGIZI, J. C. (2014). The victim-centred approach in criminal prosecutions and the need for compensation: reflections on international approaches and the legislative and policy frameworks in Uganda and South Africa. Comparative and International Law Journal of Southern Africa, 47(2), 206-224.

MEDWED. Daniel S. (2009). The Prosecutor as Minister of Justice: Preaching to the Unconverted from the Post-Conviction Pulpit. Wash. L. Rev., 84, 35. MOFFETT, L. (2016). Complementarity's Monopoly on Justice in Uganda: The International Criminal Court, Victims and Thomas Kwoyelo. International Criminal Law Review, 16(3), 503-524.

NSEREKO, D. D. N. (2005). Prosecutorial Discretion before National Courts and International Tribunals1. Journal of International Criminal Justice, 3(1), 124-144.

PAYNE-JAMES, J., BEYNON, J., \& VIEIRA, D. (Eds.). (2017). Monitoring Detention, Custody, Torture and Ill-treatment: A Practical Approach to Prevention and Documentation. CRC Press.

SHERMER, L. O. N., \& Johnson, B. D. (2010). Criminal prosecutions: Examining prosecutorial discretion and charge reductions in US federal district courts. Justice Quarterly, 27(3), 394-430.

WAGONA, V. (2014). Present Situation, Problems and Solutions in the Legal 
System Related to Corruption Control in Uganda. 8th International Training Course on Corruption Control in Criminal Justice, Resource Material Series, (71).

WAITE, P. B. (1984). An Attorney General of Nova Scotia, JSD Thompson, 1878-1882: Disparate Aspects of Law and Society in Provincial Canada. Dalhousie LJ, 8, 165.

YAROSHEFSKY, E. (2009). Enhancing the Justice Mission in the Exercise of Prosecutorial Discretion. Temp. Pol. \& Civ. Rts. L. Rev., 19, 343.

ZHEN, F. A. N. G. (2011). Role Definition of Prosecutor in the Criminal Trial: From the Perspective of Prosecution and Defense Equality [J]. Journal of Central South University of Forestry \& Technology (Social Sciences), 1, 011.

\section{Cases}

Al Skeini and Others $v$ Secretary of state for defence and Others [2007] UKHL 26 Al Skeini and Others $v$ United Kingdom (Application no. 55721/07)

Brady v Maryland 373 U.S 83 (1963)

Gäfgen v Germany Application no. 22978/05

ICC Prosecutor v Lubanga, AC, ICC-01/04-01/06-774 (OA6), 14 December 2006, Judgement on the Appeal of Mr Thomas Lubanga Dyilo against the Decision of the PTCI entitled 'Second Decision on the Prosecution Requests and amended requests for Redactions under Rule 81'

R v Lucas [1973] VLR 693

Woolmington $v$ DPP [1935] AC 462 at 481-482

\section{Legislation}

The Advocates Act

The Anti-Terrorism Act 2002

The Constitution of the Republic of Uganda 1995

The Evidence Act 1943

The Magistrates Court Act, 1970

The Penal Code Act 1950

The Prevention and Prohibition of Torture Act 2012

The Trial on Indictments Act 1971 